\section{BRAZIULAN JOURNAL \\ OF MEDICAL AND BIOLOGICAL RESEARCH}

www.bjournal.com.br
ISSN 1414-431X

Volume 45 (12) 1102-1340 December 2012

\section{BIOMIDICAL SCIENCES}

AND

CLINICAL INVESTIGATION

Braz J Med Biol Res, December 2012, Volume 45(12) 1150-1156

doi: 10.1590/S0100-879X2012007500159

Effect of hepatocyte growth factor and angiotensin II on rat cardiomyocyte hypertrophy

Ai-Lan Chen, Cai-Wen Ou, Zhao-Chu He, Qi-Cai Liu, Qi Dong and Min-Sheng Chen

The Brazilian Journal of Medical and Biological Research is partially financed by

\section{욛NPq}

Ministério

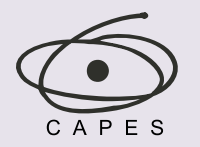

Ministério da Educação

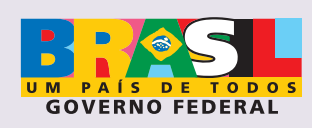

DTFAPESP

Institutional Sponsors

๑ SHIMADZu

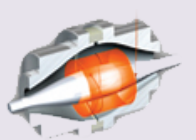

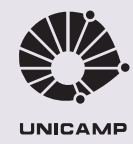
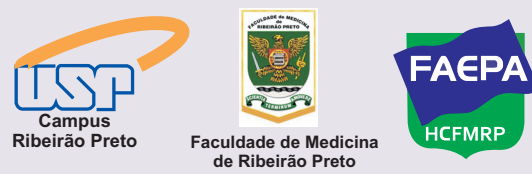

UNICAMP

lore High - Performance MS Orbitrap Technology In Proteomics \& Metabolomics

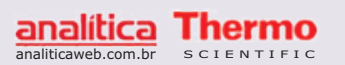




\title{
Effect of hepatocyte growth factor and angiotensin II on rat cardiomyocyte hypertrophy
}

\author{
Ai-Lan Chen ${ }^{1}$, Cai-Wen Ou², Zhao-Chu He ${ }^{1}$, Qi-Cai Liu ${ }^{3}$, Qi Dong ${ }^{4}$ and \\ Min-Sheng Chen 5 \\ ${ }^{1}$ Department of Cardiology, The First Affiliated Hospital of Guangzhou Medical University, Guangzhou, China \\ ${ }^{2}$ The Fourth Affiliated Hospital of Guangzhou Medical University, Guangzhou, China \\ ${ }^{3}$ Experimental Medical Research Center, Guangzhou Medical University, Guangzhou, China \\ ${ }^{4}$ Department of Physiology, Guangzhou Medical University, Guangzhou, China \\ ${ }^{5}$ Guangzhou Key Laboratory of Cardiovascular Disease, Guangzhou Institute of Cardiovascular Disease, \\ The Second Affiliated Hospital of Guangzhou Medical University, Guangzhou, China
}

\begin{abstract}
Angiotensin II (Ang II) plays an important role in cardiomyocyte hypertrophy. The combined effect of hepatocyte growth factor (HGF) and Ang II on cardiomyocytes is unknown. The present study was designed to determine the effect of HGF on cardiomyocyte hypertrophy and to explore the combined effect of HGF and Ang II on cardiomyocyte hypertrophy. Primary cardiomyocytes were isolated from neonatal rat hearts and cultured in vitro. Cells were treated with Ang II $(1 \mu \mathrm{M})$ alone, $\mathrm{HGF}(10 \mathrm{ng} / \mathrm{mL})$ alone, and Ang II $(1 \mu \mathrm{M})$ plus HGF $(10 \mathrm{ng} / \mathrm{mL})$ for 24,48 , and $72 \mathrm{~h}$. The amount of $\left[{ }^{3} \mathrm{H}\right]$-leucine incorporation was then measured to evaluate protein synthesis. The mRNA levels of $\beta$-myosin heavy chain and atrial natriuretic factor were determined by real-time PCR to evaluate the presence of fetal phenotypes of gene expression. The cell size of cardiomyocytes was also studied. Ang II $(1 \mu \mathrm{M})$ increased cardiomyocyte hypertrophy. Similar to Ang II, treatment with $1 \mu \mathrm{M}$ HGF promoted cardiomyocyte hypertrophy. Moreover, the combination of $1 \mu \mathrm{M}$ Ang II and $10 \mathrm{ng} / \mathrm{mL}$ HGF clearly induced a combined pro-hypertrophy effect on cardiomyocytes. The present study demonstrates for the first time a novel, combined effect of HGF and Ang II in promoting cardiomyocyte hypertrophy.
\end{abstract}

Key words: Angiotensin II; Hepatocyte growth factor; Cardiomyocyte; Hypertrophy

\section{Introduction}

Myocardial hypertrophy is defined as a thickening of the myocardium, which results in a decrease in the size of the chamber of the heart, including the left and right ventricles, and is an important risk factor for subsequent cardiac morbidity and mortality. The pathophysiology and role of cardiomyocyte hypertrophy in heart disease have been intensively investigated; however, to date they are only partially understood. Cardiac hypertrophic growth is the primary responsive mechanism by which the heart reduces stress on the ventricular wall. Conventional views suggest that cardiomyocyte hypertrophy is a compensatory response to increased hemodynamic overload, which leads to cardiac disease. However, recent findings in genetic animal models of myocardial hypertrophy as well as human studies have revealed support for a molecular basis whereby either compensatory or maladaptive forms of hypertrophy exist, and only the latter lead to cardiac failure (1). In the case of myocardial infarction, hypertrophic responses occur in cardiomyocytes in the surviving portion of the ventricle, and ventricular dilatation follows as a result of re-organization of the myocardium, including cardiomyocytes and mesenchymal cells in combination $(2,3)$. To execute this response, the cardiomyocytes are stimulated by neurohumoral factors and subsequent intracellular reactive cascade systems. All of these processes entail an increase in protein synthesis as well as the size and architectural rearrangement within individual cardiomyocytes.

Angiotensin II (Ang II), the central product of the renin-

Correspondence: Min-Sheng Chen, Guangzhou Key Laboratory of Cardiovascular Disease, Guangzhou Institute of Cardiovascular Disease, The Second Affiliated Hospital of Guangzhou Medical University, Guangzhou 510260, China. Fax: +86-20-813-40448. E-mail: gzminsheng@vip.163.com and/or chenailan5496@sina.com

Received February 27, 2012. Accepted August 5, 2012. Available online October 15, 2012. Published December 17, 2012. 
angiotensin system, is believed to be one of the most important regulators of the initiation of a positive feedback regulation of the cardiac hypertrophic response (4). In cultured cardiomyocytes, Ang II was shown to directly induce the gene expression of $\beta$-myosin heavy chain $(\beta-\mathrm{MHC})$ and atrial natriuretic factor (ANF) (4) and also increase protein synthesis and protein content (5) through the activation of angiotensin receptor I. More detailed mechanisms have been described in recent years, including involvement with mitochondrial oxidative stress (6), autophagy $(7,8)$, p70-S6 protein kinase (9), nitric oxide (10), focal adhesion kinase (11), and AMP-activated protein kinase $(12,13)$. In fact, in addition to Ang II, large numbers of intracellular or extracellular factors affect cardiomyocyte hypertrophy in vivo (14). Moreover, the influence of these factors on Ang II-induced cardiomyocyte hypertrophy is largely unknown.

In the present study, we hypothesized that there may be crosstalk between Ang II and hepatocyte growth factor (HGF) in cardiomyocyte hypertrophy. HGF is a paracrine cellular growth, motility, and morphogenic factor. It was initially isolated from fibroblasts and was shown to stimulate the motility of epithelial cells and to have a wide range of effects on many biological processes (15). Specifically, HGF acts primarily on epithelial cells, endothelial cells, and hematopoietic progenitor cells (16). It has been shown to have a major role in embryonic organ development, adult organ regeneration, and wound healing (16). In recent years, the impact of HGF on the heart or cardiomyocytes has been gradually uncovered. HGF protects the heart from ischemic/reperfusion injury, attenuates cardiac remodeling, improves angiogenesis, and induces endothelial progenitor cell mobilization (16). In our study, we first determined the effects of a single treatment of Ang II or HGF on cardiomyocytes and then examined whether the combined treatment of Ang II and HGF differed from each factor administered individually.

\section{Material and Methods}

\author{
Animals and reagents \\ Newborn Sprague-Dawley rats (18-20 g) were supplied \\ by the Animal Center of Guangzhou Medical University. Rats \\ were housed and used in accordance with our institutional \\ guidelines for animal care and the Guide for Animal Care \\ of the National Institutes of Health. Dulbecco's modified \\ Eagle's medium (DMEM), fetal bovine serum (FBS), and \\ TRIzol were purchased from Gibco BRL (USA). Trypsin \\ was obtained from Amersco (USA). Alpha-sarcomeric actin \\ was purchased from Santa Cruz Biotechnology (USA). The \\ SYBR ${ }^{\circledR}$ GreenPCR Master Mix was obtained from Applied \\ Biosystems (USA). The Thermo ScriptRT-PCR kit was \\ purchased from Invitrogen (USA). $\left.{ }^{3} \mathrm{H}\right]$-leucine (Leu) was \\ obtained from the China Institute of Atomic Energy (China) \\ and recombinant Ang II and HGF were purchased from \\ Sigma (Germany).
}

\section{Primary cardiomyocyte culture}

Rat neonatal ventricular cardiomyocytes were prepared as previously described, with some modifications (17). The cells were suspended in DMEM containing 10\% FBS and 0.1 $\mathrm{mM}$ bromodeoxyuridine and plated on either glass coverslips or polystyrene-treated Petri dishes. The cells were cultured at $37^{\circ} \mathrm{C}$ in a $5 \% \mathrm{CO}_{2}$ incubator for $72 \mathrm{~h}$. Pulsations of the cardiomyocytes were observed with an inverted biological microscope (18). In addition, the cardiomyocytes were fixed and stained by immunohistochemical methods using an anti- $\alpha$-sarcomeric actin antibody (19). The purity of the cardiomyocytes was approximately $95 \%$.

\section{Groups and treatments}

The cardiomyocyte medium was changed to serum-free DMEM for $24 \mathrm{~h}$. The cardiomyocytes were then treated with different concentrations of Ang II (0.01-10 $\mu \mathrm{M})$ and HGF $(1,10,100 \mathrm{ng} / \mathrm{mL})$ for $48 \mathrm{~h}$ in order to explore the most appropriate concentrations of each factor.

Based on these experiments, we identified an optimal treatment regimen. Cardiomyocytes were divided into four groups: Control group (0.1 M PBS), HGF-treated group (10 $\mathrm{ng} / \mathrm{mL})$, Ang II-treated group $(1 \mu \mathrm{M})$, and HGF $(10 \mathrm{ng} / \mathrm{mL})$ plus Ang II $(1 \mu \mathrm{M})$-treated group. The cells were treated with these agents for 24,48 , and $72 \mathrm{~h}$.

\section{$\left[{ }^{3} \mathrm{H}\right]$-Leu incorporation assay}

Tritiated leucine $\left(\left[{ }^{3} \mathrm{H}\right]\right.$-Leu $)$ incorporation studies were performed as previously described (20) to investigate the effects of the treatments on total protein synthesis. Cells were seeded on 24-well plates $\left(1 \times 10^{5}\right.$ cells/well) and treated with HGF $(10 \mathrm{ng} / \mathrm{mL})$ or Ang II $(1 \mu \mathrm{M})$ or HGF (10 $\mathrm{ng} / \mathrm{mL})$ plus Ang II $(1 \mu \mathrm{M})$, as described in the preceding section. Cells were then pulsed with $\left[{ }^{3} \mathrm{H}\right]$-Leu $(104 \mathrm{~Bq} / \mathrm{mL})$ for $12 \mathrm{~h}$ before the end of the treatment. At the end of the incubation, the cells were washed three times with ice-cold PBS and then disrupted by the addition of $200 \mu \mathrm{L} 0.1 \%$ sodium dodecyl sulfate and $0.1 \mathrm{~N} \mathrm{NaOH}$. The solubilized cell lysates $(100 \mu \mathrm{L})$ were added to $5 \mathrm{~mL}$ scintillation fluid. The incorporation of $\left[{ }^{3} \mathrm{H}\right]$-Leu into the protein was determined by scintillation counting. Incorporation is reported as the ratio: $\left[{ }^{3} \mathrm{H}\right]$-Leu incorporation/number of cells.

\section{RNA extraction and real-time PCR analysis}

After the cells were treated with HGF $(10 \mathrm{ng} / \mathrm{mL})$, Ang II $(1 \mu \mathrm{M})$, or HGF $(10 \mathrm{ng} / \mathrm{mL})$ plus Ang II $(1 \mu \mathrm{M})$ for $12 \mathrm{~h}$, they were washed with ice-cold PBS buffer. Total RNA was extracted from the cells using Trizol (21), and $1 \mu \mathrm{g}$ RNA was reverse transcribed to cDNA using Thermo ScriptRTPCR (22). Real-time PCR was performed using an Applied Biosystems 7500 fast real-time PCR system and SYBR Premix Ex Taq mixture with specific primers (Sangon, China) (23). The PCR assays were initiated with a denaturation step at $95^{\circ} \mathrm{C}$ for $10 \mathrm{~s}$, followed by amplification with 40 cycles at $95^{\circ} \mathrm{C}$ for $10 \mathrm{~s}$ and annealing at $60^{\circ} \mathrm{C}$ for $20 \mathrm{~s}$ 
(two-step method) (24). Finally, a melting curve analysis was performed from $60^{\circ}$ to $85^{\circ} \mathrm{C}$. Data were evaluated with the Applied Biosystems software. The following primers designed with the Primer Express Software (Applied Biosystems) were used: ANF: 5'-AAA GCAAAC TGA GGG CT-3' (sense) and 5'-GGG ATC TTT TGC GAT CT-3' (antisense); $\beta-M H C$ : 5'-TGC AGT TAA AGG TGA AGG C-3' (sense) and 5'-CAG GGC TTC ACA GGC AT-3' (antisense); glyceraldehyde 3-phosphate dehydrogenase (GAPDH): 5'CGG AGT CAA CGG ATT TGG TGG TAT-3' (sense) and 5'-AGC CTT CTC CAT GGT GGT GAA GAC-3' (antisense). GAPDH was used as an internal control and the amount of target was defined by the $2^{\Delta \Delta \mathrm{Ct}}$ method (25).

\section{Measurement of cell size}

Cardiomyocytes were seeded on 24-well plates and cultured for $48 \mathrm{~h}$. After treatment with HGF (10 ng/mL), Ang II $(1 \mu \mathrm{M})$, or HGF (10 ng/mL) plus Ang II (1 $\mu \mathrm{M})$ for 12 $\mathrm{h}$, the cells were digested with EDTA-trypsin $(0.25 \%)$ for 5 min, $10 \%$ FBS was used to terminate the reaction and the average cell size was determined using the Image $\mathrm{J}$ software (http://rsb.info.nih.gov/ij/download.html) as previously described (26). The average cell size was determined by observation of 150 cells (50 cells/well $\times 3$ wells).

\section{Statistical analysis}

Data are reported as means \pm SD. The differences were evaluated by a two-tailed Student $t$-test ( 2 groups) or one-way analysis of variance (ANOVA) followed by the Tukey post hoc test (3 or more groups) using the SPSS software (version 9.0, USA) (27). Statistical significance was set at $P<0.05$.

\section{Results}

Effects of Ang II on $\left[{ }^{3} \mathrm{H}\right]$-Leu incorporation and on ANF and $\beta$-MHC mRNA levels in primary cardiomyocytes

As shown in Table 1 , Ang II $(0.01 \mu \mathrm{M})$ caused a slight but significant increase in $\left[{ }^{3} \mathrm{H}\right]$-Leu incorporation compared to control $(1494.58 \pm 65.00$ vs $1188.83 \pm 72.20 \mathrm{cpm} /$ well, respectively; $P<0.05)$. However, at this concentration of
Ang II, the mRNA levels of ANF and $\beta-\mathrm{MHC}$ in primary cardiomyocytes were not changed.

When Ang II was administered at a higher concentration $(0.1 \mu \mathrm{M})$, the $\left[{ }^{3} \mathrm{H}\right]$-Leu incorporation increased to 1820 $\mathrm{cpm} /$ well, which was approximately 1.5 -fold higher than the control group $(P<0.01)$. In addition, this concentration of Ang II also significantly enhanced the mRNA levels of ANF (1.2-fold, $\mathrm{P}<0.01)$ and $\beta-\mathrm{MHC}(1.75$-fold, $\mathrm{P}<0.01)$.

When the Ang II concentration was increased to $1 \mu \mathrm{M}$, the amount of $\left[{ }^{3} \mathrm{H}\right]$-Leu incorporation increased approximately 2-fold compared to the control group (2374.08 \pm 49.34 vs $1188.83 \pm 72.20 \mathrm{cpm} /$ well, respectively; $\mathrm{P}<0.01$ ), while the mRNA levels of ANF and $\beta-\mathrm{MHC}$ increased by $44 \%(P<0.01)$ and $85 \%(P<0.01)$, respectively.

The highest concentration of Ang II tested $(10 \mu \mathrm{M})$ increased the $\left[{ }^{3} \mathrm{H}\right]$-Leu incorporation only slightly $(2414.67 \pm$ 56.70 vs $1188.83 \pm 72.20 \mathrm{cpm} /$ well, respectively; $\mathrm{P}<0.01$ ). Moreover, at this concentration of Ang II, the mRNA levels of ANF and $\beta-\mathrm{MHC}$ only increased by 1.65 -fold and 2.08 fold, respectively. Therefore, we chose $1 \mu \mathrm{M}$ as the optimal concentration of Ang II for subsequent experiments.

\section{Effects of HGF on $\left[{ }^{3} \mathrm{H}\right]$-Leu incorporation and on ANF and $\beta-M H C$ mRNA levels in primary cardiomyocytes}

We sought to determine the effects of different concentrations of $\mathrm{HGF}$ on $\left[{ }^{3} \mathrm{H}\right]$-Leu incorporation as well as on mRNA levels of ANF and $\beta-M H C$ in primary cardiomyocytes. As shown in Table 2, administration of $1 \mathrm{ng} / \mathrm{mL}$ HGF significantly increased the $\left[{ }^{3} \mathrm{H}\right]$-Leu incorporation in cardiomyocytes to $2430.47 \pm 72.65 \mathrm{cpm} /$ well, which was approximately 2.2-fold higher than the control group $(\mathrm{P}<$ $0.01)$. Moreover, HGF at this concentration also significantly $(P<0.01)$ enhanced the mRNA levels of ANF $(2.33$-fold $)$ and $\beta-\mathrm{MHC}$ (2.14-fold).

When the HGF concentration was increased to 10 $\mathrm{ng} / \mathrm{mL}$, the $\left[{ }^{3} \mathrm{H}\right]$-Leu incorporation was higher compared to control $(3848 \pm 71.57$ vs $1113.45 \pm 62.58 \mathrm{cpm} /$ well, respectively; $\mathrm{P}<0.01)$. Moreover, the ANF and $\beta-\mathrm{MHC}$ mRNA levels were also increased (3.32- and 2.81-fold, respectively; $\mathrm{P}<0.01)$. Interestingly, the highest concentration of HGF $(100 \mathrm{ng} / \mathrm{mL})$ did not further increase $\left[{ }^{3} \mathrm{H}\right]$-Leu

Table 1. Effects of different concentrations of Ang II on $\left[{ }^{3} \mathrm{H}\right]$-Leu incorporation, and mRNA levels of ANF and $\beta-\mathrm{MHC}$ in primary cardiomyocytes.

\begin{tabular}{lccc}
\hline Ang II $(\mu \mathrm{M})$ & {$\left[{ }^{3} \mathrm{H}\right]$-Leu incorporation $(\mathrm{cpm} /$ well) } & Relative ANF mRNA & Relative $\beta$-MHC mRNA \\
\hline Control & $1188.83 \pm 72.20$ & $1 \pm 0$ & $1 \pm 0$ \\
0.01 & $1494.58 \pm 65.00^{*}$ & $1.07 \pm 0.09$ & $1.17 \pm 0.06$ \\
0.1 & $1821.33 \pm 54.65^{*}$ & $1.20 \pm 0.02^{*}$ & $1.75 \pm 0.03^{*}$ \\
1 & $2374.08 \pm 49.34^{*}$ & $1.44 \pm 0.08^{*}$ & $1.85 \pm 0.13^{*}$ \\
10 & $2414.67 \pm 56.70^{*}$ & $1.65 \pm 0.04^{*}$ & $2.08 \pm 0.14^{*}$ \\
\hline
\end{tabular}

Data reported as means $\pm S D$ for $N=6$ /concentration performed in triplicate. Ang II = angiotensin II; ANF $=$ atrial natriuretic factor; $\beta-\mathrm{MHC}=\beta$-myosin heavy chain. ${ }^{*} \mathrm{P}<0.05$ vs control (one-way ANOVA). 
Table 2. Effects of different concentrations of HGF on $\left[{ }^{3} \mathrm{H}\right]$-Leu incorporation, and mRNA levels of $\mathrm{ANF}$ and $\beta-\mathrm{MHC}$ in primary cardiomyocytes.

\begin{tabular}{lccc}
\hline HGF $(\mathrm{ng} / \mathrm{mL})$ & {$\left[{ }^{3} \mathrm{H}\right]$-Leu incorporation (cpm/well) } & Relative ANF mRNA & Relative $\beta$-MHC mRNA \\
\hline Control & $1113.45 \pm 62.58$ & $1 \pm 0$ & $1 \pm 0$ \\
1 & $2430.47 \pm 72.65^{*}$ & $2.33 \pm 0.04^{*}$ & $2.14 \pm 0.03^{*}$ \\
10 & $3848 \pm 71.57^{*}$ & $3.32 \pm 0.08^{*}$ & $2.81 \pm 0.07^{*}$ \\
100 & $3256 \pm 68.34^{*}$ & $3.01 \pm 0.01^{*}$ & $2.42 \pm 0.06^{*}$ \\
\hline
\end{tabular}

Data are reported as means $\pm \mathrm{SD}$ for $\mathrm{N}=6$ /concentration performed in triplicate. $\mathrm{HGF}=$ hepatology growth factor; ANF = atrial natriuretic factor; $\beta-\mathrm{MHC}=\beta$-myosin heavy chain. ${ }^{*} \mathrm{P}<0.05$ vs control (one-way ANOVA).

incorporation or ANF and $\beta-\mathrm{MHC}$ mRNA levels compared to the lower concentration of HGF $(10 \mathrm{ng} / \mathrm{mL})$. Therefore, we chose $10 \mathrm{ng} / \mathrm{mL}$ as the optimal concentration of HGF in subsequent experiments.

\section{Effects of HGF in combination with Ang II on $\left[{ }^{3} \mathrm{H}\right]-$ Leu incorporation and on ANF and $\beta-M H C$ mRNA levels in primary cardiomyocytes}

We next investigated whether HGF and Ang II had combined effects on cardiomyocytes. Ang II and HGF in combination induced a significant increase in $\left[{ }^{3} \mathrm{H}\right]$-Leu incorporation and in ANF mRNA and $\beta-M H C$ mRNA levels (Figure 1A-C). Interestingly, the HGF-induced cardiomyocyte hypertrophy was even greater than Ang II-induced hypertrophy (Figure $1 \mathrm{~A}-\mathrm{C}$ ).

Compared to the HGF $(10 \mathrm{ng} / \mathrm{mL})$ or Ang II $(1 \mu \mathrm{M})$ groups, the combined treatment of HGF $(10 \mathrm{ng} / \mathrm{mL})$ and Ang II $(1 \mu \mathrm{M})$ increased $\left[{ }^{3} \mathrm{H}\right]$-Leu incorporation even further at 24,48 , and $72 \mathrm{~h}$ (Figure $1 \mathrm{~A} ; \mathrm{P}<0.01$ ). Similarly, combined treatment of cardiomyocytes with $\mathrm{HGF}(10 \mathrm{ng} / \mathrm{mL})$ and Ang II $(1 \mu \mathrm{M})$ significantly upregulated the mRNA levels of ANF (Figure 1B) and $\beta-\mathrm{MHC}$ (Figure 1C) compared to separate treatment with HGF $(10 \mathrm{ng} / \mathrm{mL})$ or Ang II $(1 \mu \mathrm{M})$ alone at these time points.

\section{Effect of HGF and Ang II on the cell size of primary cardiomyocytes}

We also determined the effect of HGF and Ang II on cardiomyocyte cell size. Compared to the control group, both the HGF (10 ng/mL)-treated group and Ang II (1 $\mu \mathrm{M})$ treated group showed an increase in cell size (Figure 2). The combination treatment of HGF and Ang II increased the cell size of cardiomyocytes further (Figure 2).

\section{Discussion}

This study was the first to directly assess whether there was a combined effect of HGF and Ang II on cardiomyocyte hypertrophy. Based on the increase in $\left[{ }^{3} \mathrm{H}\right]$-Leu incorporation, the increased ANF and $\beta-\mathrm{MHC}$ mRNA expression and the increase in cell size in primary cardiomyocytes, we concluded that HGF and Ang II have a combined effect on neonatal cardiomyocyte
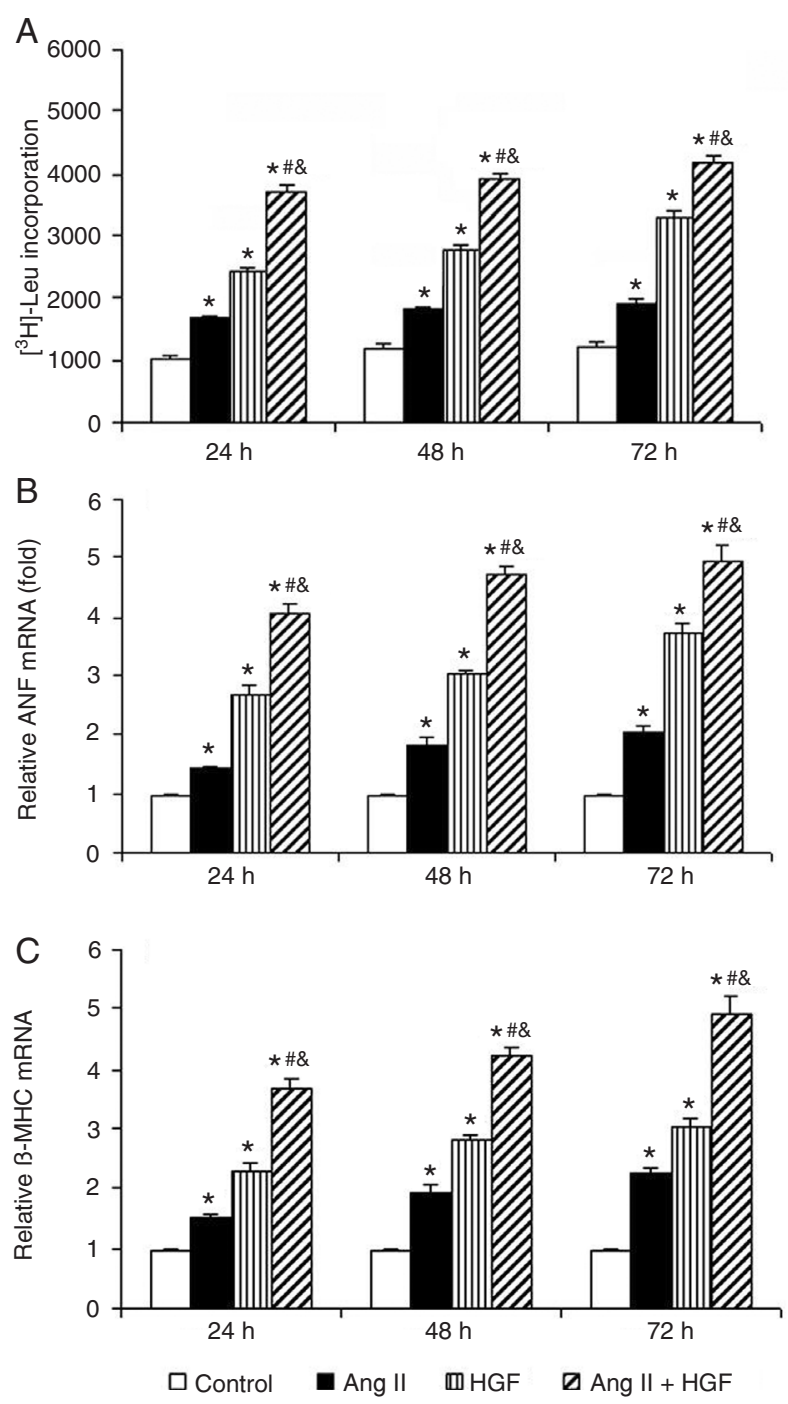

Figure 1. Effects of Ang II $(1 \mu \mathrm{M})$, HGF $(10 \mathrm{ng} / \mathrm{mL})$, and HGF (10 $\mathrm{ng} / \mathrm{mL}$ ) plus Ang II $(1 \mu \mathrm{M})$ on $\left[{ }^{3} \mathrm{H}\right]$-Leu incorporation $(A)$, the mRNA levels of ANF $(B)$ and the mRNA levels of $\beta-M H C(C)$ in primary cardiomyocytes. $N=8$ per group. The experiments were repeated three times. HGF = hepatology growth factor; Ang II = angiotensin II; ANF = atrial natriuretic factor; $\beta-\mathrm{MHC}=\beta$-myosin heavy chain. ${ }^{*} \mathrm{P}<0.05$ vs control; ${ }^{\#} \mathrm{P}<0.05$ vs HGF; ${ }^{\circledR} \mathrm{P}<0.05$ vs Ang II (one-way ANOVA). 
hypertrophy. In addition, we also demonstrated for the first time that HGF alone can potently induce cultured neonatal cardiomyocyte hypertrophy.

In this study, we first found that HGF could induce cardiomyocyte hypertrophy. To our surprise, the HGF-induced cardiomyocyte hypertrophy was even greater than Ang II-induced hypertrophy (Figure $1 \mathrm{~A}-\mathrm{C}$ ). The presence of the HGF receptor on cardiomyocytes was first confirmed by Akiyama et al. (28). Subsequently, several independent reports have demonstrated a protective effect of HGF on myocardial infarction in vivo $(29,30)$. However, as yet the underlying mechanisms for the pro-hypertrophy of cardiomyocytes are not clear. Moreover, the results of in vivo experiments cannot exclude the possibility that HGF treatment stimulates cardiac fibroblasts (31) and thereby releases factors that induce hypertrophy of the surrounding cardiomyocytes. Pathological cardiomyocyte hypertrophy is characterized not only by an increase in cardiomyocyte size, but also by cardiomyocyte gene reprogramming, as shown by the enhanced expression of fetal phenotypes of genes, such as skeletal $\alpha$-actin, $\beta-M H C$, and ANF (32). In our study, we evaluated cell hypertrophy by determining $\left[{ }^{3} \mathrm{H}\right]$-Leu incorporation and the average cell size as well as ANF and $\beta-M H C$ mRNA levels. Based on these various parameters, we have clearly shown that HGF can directly induce cardiomyocyte hypertrophy. It should be noted that Nakamura et al. (33) demonstrated an interference of administered HGF on cardiomyopathy remodeling in hamster hearts. The authors found a direct negative effect of HGF on the transcript levels of ANF. In the present study, we showed an inductive effect of HGF on ANF levels, in agreement with a previous report (34). We considered that this disparity might be due to the species difference.

Based on these findings, we sought to determine how this pro-hypertrophy effect of HGF may occur. Since the most common cause of cardiomyocyte hypertrophy is hypertension, and since an increased Ang II level in hypertension is a critical pro-hypertrophy trigger, we next explored whether there might be an association between HGF and Ang II in cardiomyocytes. Importantly, we found a combined effect of HGF and Ang II on cardiomyocyte hypertrophy. The roles of Ang II in the regulation of the cardiovascular system under normal and pathological conditions have been well documented, and it has been well accepted that Ang II is a direct pro-hypertrophy factor in cardiomyocytes. Moreover, there is evidence that Ang II and related proteins such as interleukin-1 $\beta$ and tumor necrosis factor- $\alpha$, play key roles in cardiac fibroblast growth and collagen deposition following myocardial infarction (35). In addition, heparin, a highly sulfated glycosaminoglycan and widely used injectable anticoagulant, was found to potently inhibit Ang II-mediated cardiomyocyte hypertrophy (36). The interleukin-6 family of cytokines was also reported to contribute to Ang II-

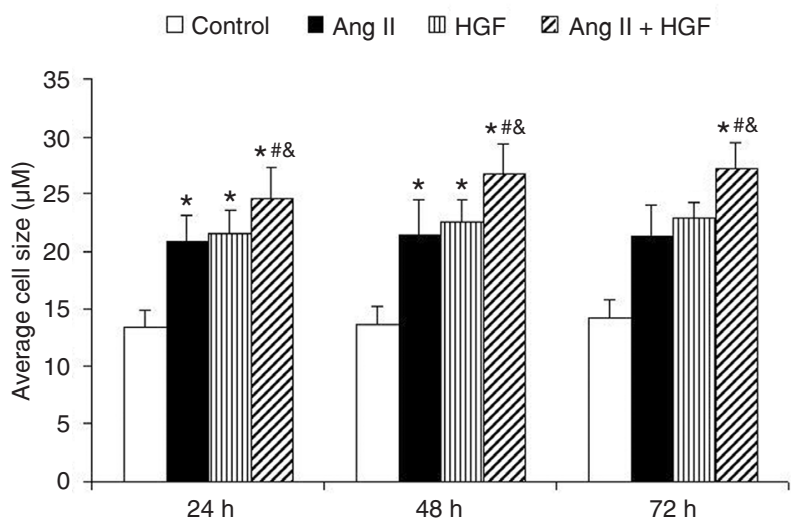

Figure 2. Effects of Ang II $(1 \mu \mathrm{M}), \mathrm{HGF}(10 \mathrm{ng} / \mathrm{mL})$, and HGF (10 $\mathrm{ng} / \mathrm{mL}$ ) plus Ang II $(1 \mu \mathrm{M})$ on average cell size. $\mathrm{N}=8$ per group. The experiments were repeated three times. HGF $=$ hepatology growth factor; Ang II = angiotensin II. *P $<0.05$ vs control; ${ }^{*} \mathrm{P}<$ 0.05 vs HGF; \&P < 0.05 vs Ang II (one-way ANOVA).

induced cardiomyocyte hypertrophy (37). However, to the best of our knowledge, there has been no report to date on the combined effect of Ang II and any other protein on cardiomyocyte hypertrophy. More importantly, since cardiomyocyte hypertrophy is related to the pathophysiological mechanisms of many cardiovascular diseases, our findings in this study may bring new focus on HGF in treating cardiovascular diseases.

One limitation of this study is that the molecular mechanisms underlying the combined effect of Ang II and HGF on cardiomyocyte hypertrophy remain to be elucidated. It has been reported that post-infarction HGF gene therapy resulted in substantial cardiomyocte hypertrophy at the edges of the infarcted tissue, accompanied by the overexpression of the HGF receptor (c-Met), which is a transmembrane tyrosine kinase through which HGF activates the Ras-Raf-MEK-ERK signaling pathway, thereby contributing to myocardial hypertrophy (38). The c-Met is also a receptor for the scatter factor (SF) (39). The activation of c-Met by HGF/SF can elicit a variety of cellular responses including proliferation, migration, invasion, and branching morphogenesis. These processes are associated with several signaling pathways such as PI3K/Akt, Src, and STAT3 (39). Moreover, these signaling pathways also contribute to Ang II-induced hypertrophy. Aoki et al. (40) have shown that the ERK pathway has an important role in Ang II-induced cardiac hypertrophy. Moreover, the PI3K/Akt, Src, and STAT3 pathways have also been reported to be vital controllers in Ang II-induced cardiac hypertrophy. Therefore, it may be difficult to determine the exact underlying molecular mechanisms of the combined effect of HGF and Ang II on cardiomyocyte hypertrophy. The convergence point between HGF and Ang II needs to be further elucidated in future experiments. 
Our study has provided the first evidence that HGF and Ang II administered in combination induce cardiomyocyte hypertrophy. This finding was supported by the changes observed in protein synthesis, the presence of fetal phenotypes of gene expression (ANF and $\beta-\mathrm{MHC}$ ), an increase in cell size, and ultrastructural changes of neonatal cardiomyocytes. These results may help to improve the management and treatment of patients with cardiac hypertrophy.

\section{References}

1. Lips DJ, deWindt LJ, van Kraaij DJ, Doevendans PA. Molecular determinants of myocardial hypertrophy and failure: alternative pathways for beneficial and maladaptive hypertrophy. Eur Heart J 2003; 24: 883-896.

2. Li Q, Li B, Wang X, Leri A, Jana KP, Liu Y, et al. Overexpression of insulin-like growth factor-1 in mice protects from myocyte death after infarction, attenuating ventricular dilation, wall stress, and cardiac hypertrophy. J Clin Invest 1997; 100: 1991-1999.

3. Orlic D, Kajstura J, Chimenti S, Jakoniuk I, Anderson SM, $\mathrm{Li} \mathrm{B}$, et al. Bone marrow cells regenerate infarcted myocardium. Nature 2001; 410: 701-705.

4. Sadoshima J, Izumo S. Molecular characterization of angiotensin II-induced hypertrophy of cardiac myocytes and hyperplasia of cardiac fibroblasts. Critical role of the AT1 receptor subtype. Circ Res 1993; 73: 413-423.

5. Wada H, Zile MR, Ivester CT, Cooper G, McDermott PJ. Comparative effects of contraction and angiotensin II on growth of adult feline cardiocytes in primary culture. Am J Physiol 1996; 271: H29-H37.

6. Dai DF, Rabinovitch P. Mitochondrial oxidative stress mediates induction of autophagy and hypertrophy in angiotensinII treated mouse hearts. Autophagy 2011; 7: 917-918.

7. Gottlieb RA, Mentzer RM Jr, Linton PJ. Impaired mitophagy at the heart of injury. Autophagy 2011; 7: 1573-1574.

8. Zois CE, Giatromanolaki A, Sivridis E, Papaiakovou M, Kainulainen H, Koukourakis MI. "Autophagic flux" in normal mouse tissues: focus on endogenous LC3A processing. Autophagy 2011; 7: 1371-1378.

9. Jonassen AK, Sack MN, Mjos OD, Yellon DM. Myocardial protection by insulin at reperfusion requires early administration and is mediated via Akt and p70s6 kinase cell-survival signaling. Circ Res 2001; 89: 1191-1198.

10. Landmesser $U$, Engberding $N$, Bahlmann $F H$, Schaefer $A$, Wiencke A, Heineke A, et al. Statin-induced improvement of endothelial progenitor cell mobilization, myocardial neovascularization, left ventricular function, and survival after experimental myocardial infarction requires endothelial nitric oxide synthase. Circulation 2004; 110: 1933-1939.

11. Taylor JM, Rovin JD, Parsons JT. A role for focal adhesion kinase in phenylephrine-induced hypertrophy of rat ventricular cardiomyocytes. J Biol Chem 2000; 275: 19250-19257.

12. Timmers L, Sluijter JP, Verlaan CW, Steendijk P, Cramer MJ, Emons M, et al. Cyclooxygenase-2 inhibition increases mortality, enhances left ventricular remodeling, and impairs systolic function after myocardial infarction in the pig. Circulation 2007; 115: 326-332.

13. Xie Z, He C, Zou MH. AMP-activated protein kinase modu-

\section{Acknowledgments}

Research supported by the National Natural Science Foundation of China (Grant \#30570759), the Natural Science Foundation of Guangdong Province, China (\#S201101004269) and the Foundation of Guangzhou Municipal Health Bureau Scientific Research and Education Managment System (\#201102A213125).

lates cardiac autophagy in diabetic cardiomyopathy. Autophagy 2011; 7: 1254-1255.

14. Rohini A, Agrawal N, Koyani CN, Singh R. Molecular targets and regulators of cardiac hypertrophy. Pharmacol Res 2010; 61: 269-280.

15. Funakoshi $\mathrm{H}$, Nakamura $\mathrm{T}$. Hepatocyte growth factor: from diagnosis to clinical applications. Clin Chim Acta 2003; 327: 1-23.

16. Morishita R, Aoki M, Yo Y, Ogihara T. Hepatocyte growth factor as cardiovascular hormone: role of HGF in the pathogenesis of cardiovascular disease. Endocr J 2002; 49: 273284.

17. Simpson P, McGrath A, Savion S. Myocyte hypertrophy in neonatal rat heart cultures and its regulation by serum and by catecholamines. Circ Res 1982; 51: 787-801.

18. Mellor KM, Reichelt ME, Delbridge LM. Autophagy anomalies in the diabetic myocardium. Autophagy 2011; 7 : 12631267.

19. Przyklenk K, Undyala VV, Wider J, Sala-Mercado JA, Gottlieb RA, Mentzer RM Jr. Acute induction of autophagy as a novel strategy for cardioprotection: getting to the heart of the matter. Autophagy 2011; 7: 432-433.

20. Huang Z, Li J, Jiang Z, Qi Y, Tang C, Du J. Effects of adrenomedullin, C-type natriuretic peptide, and parathyroid hormone-related peptide on calcification in cultured rat vascular smooth muscle cells. J Cardiovasc Pharmacol 2003; 42: 89-97.

21. Dong LW, Hou YJ, Tan YX, Tang L, Pan YF, Wang M, et al. Prognostic significance of Beclin 1 in intrahepatic cholangiocellular carcinoma. Autophagy 2011; 7: 1222-1229.

22. Cottam EM, Maier HJ, Manifava M, Vaux LC, ChandraSchoenfelder P, Gerner W, et al. Coronavirus nsp6 proteins generate autophagosomes from the endoplasmic reticulum via an omegasome intermediate. Autophagy 2011; 7: 13351347.

23. Wang P, Xu TY, Guan YF, Su DF, Fan GR, Miao CY. Perivascular adipose tissue-derived visfatin is a vascular smooth muscle cell growth factor: role of nicotinamide mononucleotide. Cardiovasc Res 2009; 81: 370-380.

24. Wang P, Zhang RY, Song J, Guan YF, Xu TY, Du H, et al. Loss of AMP-activated protein kinase-alpha2 impairs the insulin-sensitizing effect of calorie restriction in skeletal muscle. Diabetes 2012; 61: 1051-1061.

25. Yang J, Zhao Y, Ma K, Jiang FJ, Liao W, Zhang P, et al. Deficiency of hepatocystin induces autophagy through an mTOR-dependent pathway. Autophagy 2011; 7: 748-759.

26. Wang P, Xu TY, Guan YF, Tian WW, Viollet B, Rui YC, et al. Nicotinamide phosphoribosyltransferase protects against 
ischemic stroke through SIRT1-dependent adenosine monophosphate-activated kinase pathway. Ann Neurol 2011; 69: 360-374.

27. Trocoli A, Mathieu J, Priault M, Reiffers J, Souquere S, Pierron $\mathrm{G}$, et al. ATRA-induced upregulation of Beclin 1 prolongs the life span of differentiated acute promyelocytic leukemia cells. Autophagy 2011; 7: 1108-1114.

28. Akiyama $Y$, Ashizawa $N$, Seto $S$, Ohtsuru A, Kuroda $H$, Ito $\mathrm{M}$, et al. Involvement of receptor-type tyrosine kinase gene families in cardiac hypertrophy. J Hypertens 1999; 17: 13291337.

29. Ueda H, Nakamura T, Matsumoto K, Sawa $Y$, Matsuda $H$, Nakamura T. A potential cardioprotective role of hepatocyte growth factor in myocardial infarction in rats. Cardiovasc Res 2001; 51: 41-50.

30. Jin H, Yang R, Li W, Ogasawara AK, Schwall R, Eberhard $\mathrm{DA}$, et al. Early treatment with hepatocyte growth factor improves cardiac function in experimental heart failure induced by myocardial infarction. J Pharmacol Exp Ther 2003; 304: 654-660.

31. Taniyama $Y$, Morishita $R$, Nakagami $H$, Moriguchi A, Sakonjo $\mathrm{H}$, Shokei $\mathrm{K}$, et al. Potential contribution of a novel antifibrotic factor, hepatocyte growth factor, to prevention of myocardial fibrosis by angiotensin II blockade in cardiomyopathic hamsters. Circulation 2000; 102: 246-252.

32. Kim S, Iwao H. Molecular and cellular mechanisms of angiotensin II-mediated cardiovascular and renal diseases. Pharmacol Rev 2000; 52: 11-34.

33. Nakamura T, Matsumoto K, Mizuno S, Sawa Y, Matsuda $\mathrm{H}$, Nakamura T. Hepatocyte growth factor prevents tissue fibrosis, remodeling, and dysfunction in cardiomyopathic hamster hearts. Am J Physiol Heart Circ Physiol 2005; 288: $\mathrm{H} 2131-\mathrm{H} 2139$.

34. Roggia C, Ukena C, Bohm M, Kilter H. Hepatocyte growth factor (HGF) enhances cardiac commitment of differentiating embryonic stem cells by activating PI3 kinase. Exp Cell Res 2007; 313: 921-930.

35. Ho CY. Hypertrophic cardiomyopathy. Heart Fail Clin 2010; 6: $141-159$

36. Akimoto $\mathrm{H}$, Ito $\mathrm{H}$, Tanaka $\mathrm{M}$, Adachi S, Hata M, Lin M, et al. Heparin and heparan sulfate block angiotensin II-induced hypertrophy in cultured neonatal rat cardiomyocytes. A possible role of intrinsic heparin-like molecules in regulation of cardiomyocyte hypertrophy. Circulation 1996; 93: 810-816.

37. Sano M, Fukuda K, Kodama H, Pan J, Saito M, Matsuzaki $\mathrm{J}$, et al. Interleukin- 6 family of cytokines mediate angiotensin II-induced cardiac hypertrophy in rodent cardiomyocytes. $J$ Biol Chem 2000; 275: 29717-29723.

38. Li Y, Takemura G, Kosai K, Yuge K, Nagano S, Esaki M, et al. Postinfarction treatment with an adenoviral vector expressing hepatocyte growth factor relieves chronic left ventricular remodeling and dysfunction in mice. Circulation 2003; 107: 2499-2506.

39. Gao CF, Vande Woude GF. HGF/SF-Met signaling in tumor progression. Cell Res 2005; 15: 49-51.

40. Aoki H, Richmond M, Izumo S, Sadoshima J. Specific role of the extracellular signal-regulated kinase pathway in angiotensin II-induced cardiac hypertrophy in vitro. Biochem $\mathrm{J}$ 2000; 347 (Part 1): 275-284. 